\title{
Cryptic diversity of Aglaoctenus lagotis (Araneae, Lycosidae) in the Brazilian Atlantic Rainforest: evidence from microsatellite and mitochondrial DNA sequence data
}

\author{
Camila Menezes Trindade Macrini*, Elen Arroyo Peres, Vera Nisaka Solferini \\ Laboratório de Diversidade Genética e Programa de Pós-graduação em Genética e Biologia Molecular, Instituto de Biologia, Universidade Estadual de \\ Campinas, Campinas SP, Brazil.
}

\begin{tabular}{|c|c|}
\hline ARTICLE INFO & ABSTRACT \\
\hline Article history: & \multirow{7}{*}{$\begin{array}{l}\text { Tropical Spiders have been poorly studied, and studies regarding the distribution of genetic diversity in natural } \\
\text { populations of these species are even more scarce. Among the spider genera, the South American genus } \\
\text { Aglaoctenus includes species that build tube-shaped webs and display sub-social behavior that includes parental } \\
\text { care. Herein we studied the population genetics of Aglaoctenus lagotis in five primary fragments of the Brazilian } \\
\text { Atlantic Forest (with varying distances between } 2 \text { and } 47 \mathrm{~km} \text { ) considered a conservation hotspot. In this study, } \\
\text { we used two molecular markers: microsatellites and the COI mitochondrial gene. The data obtained indicated the } \\
\text { presence of two genetic lineages (A and B), as evidenced by both markers, suggesting the presence of cryptic } \\
\text { diversity. Lineages subpopulations are not completely isolated and have moderate structure }\left(\mathrm{F}_{\mathrm{ST}} \mathrm{A}=0.118 ; \mathrm{F}_{\mathrm{ST}} \mathrm{B}=\right. \\
0.142 \text { ). Dispersal by air (or ballooning) must occur and possibly allows the maintenance of gene flow between } \\
\text { sample sites. The hypotheses that lineages found here represent distinct species cannot be confirmed until further } \\
\text { studies have been carried out. However, regardless of its taxonomic classification, the genetic lineages, found } \\
\text { here, should be considered as individual units in future evolutionary studies of this species. }\end{array}$} \\
\hline Received on: $28 / 10 / 2015$ & \\
\hline Revised on: $12 / 11 / 2015$ & \\
\hline Accepted on: $30 / 11 / 2015$ & \\
\hline Available online: $19 / 12 / 2015$ & \\
\hline Key words: & \\
\hline $\begin{array}{l}\text { Conservation, population } \\
\text { genetics, fragmentation, } \\
\text { spider. }\end{array}$ & \\
\hline
\end{tabular}

\section{INTRODUCTION}

Spiders (Arachnida: Araneae) make up a very significant portion of all terrestrial arthropods and are widely distributed throughout the world, except in Antarctica [1]. Brazil is one of the areas of the world with the highest diversity of spiders, and out of the 112 families of spiders in the world [2], 72 have records for this country [3,4]. Despite this, spiders are poorly studied and only about $30 \%$ of the Brazilian species are esimated to have been described [5]. Lycosidae is one of the most abundant and diverse arachnid families with 2.393 known species [1], made up mostly of wandering active or ambush foragers $[6,7,8]$. Commonly, the females of this family exhibit parental care that includes producing and transporting the ootheca $[9,10]$. The spiders of the South American genus Aglaoctenus are an exception in Lycosidae since they use their silk to build webs and remain in the webs for an extended length

\footnotetext{
* Corresponding Author

Camila Menezes Trindade Macrini, Laboratório de Diversidade Genética e Programa de Pós-graduação em Genética e Biologia Molecular, Instituto de Biologia, Universidade Estadual de Campinas, Campinas SP, Brazil.Email:camilamacrini@yahoo.com.br
}

of time [11]. Holmberg 1876 builds a flat sheet from which a funnel shaped tube leads to its refuge [12]. In this species, maternal care, that includes feeding of juveniles with predigested prey, extends until five days after hatching $[10,7]$. When the juveniles leave the maternal web they settle next to it, which could explain the aggregated configuration of individuals in populations of the genus Aglaoctenus [3]. Occurring from Southeastern Brazil to northern Argentina [3], Aglaoctenus is present in several distinct ecosystems such as savannas and forests [10].

One of its habitats, the Brazilian Atlantic Forest (BAF), is a highly fragmented and threatened domain [13], considered to be a conservation hotspot [14]. Human-caused forest loss and fragmentation have been changing landscape configuration of $\mathrm{BAF}$, with important consequences on the community structure and population dynamics $[15,16,17,18,19]$ including significant effects for the spider taxa [20] Despite being an abundant and singular species, Aglacotenus lagotis has been poorly studied [21], furthermore is still lacking information that could reveal more about population dynamics in this species, including familiar aggregation and connection between forest patches. Thus, this study proposes to investigate the genetic distribution of Aglaoctenus lagotis populations in forest fragments in the BAF of southeastern Brazil using microsatellite and mtDNA markers. 


\section{MATERIALS AND METHODS}

\section{Study Region and Sample Methods}

For the present work, were collected 132 samples between January and May, typically rainy months (59 to 243.3 $\mathrm{mm} / \mathrm{month}$ ), when there is a considerable abundance of spiders.

Five populations of Aglaoctenus lagotis were studied from the following forest fragments (Figure 1): 1) Santo Antônio das Mangueiras Farm (ANT), located in the Environmental Protection Area (EPA) of Sousas and Joaquim Egidio, Campinas, SP, 2) Ribeirão Cachoeira (RC) located in the Environmental Protection Area of Sousas and Joaquim Egidio, Campinas, SP; 3) Abrahão de Moraes Observatory (VAL), Valinhos, SP; 4 and 5) Serra do Japi (JAPI 1 and JAPI 2), Jundiaí, SP. Geographical distances in kilometers ranged from 2 to $3 \mathrm{~km}$ between sampling points in the same municipality; approximately between 20 and 26 $\mathrm{km}$ between the intermediary collection point (VAL) and the others, and between 45 and $47 \mathrm{~km}$ between the furthest points (Campinas_ ANT and RC_ sample locations and Jundiaí_ JAPI1 and JAPI 2_sample locations).

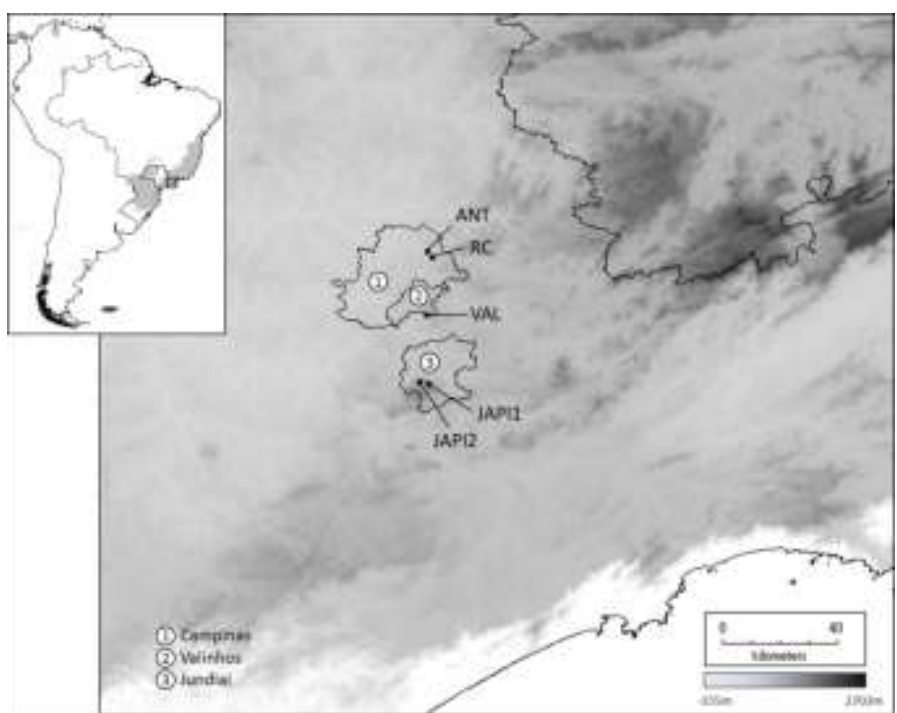

Fig. 1: Study area and colecting points. 1) Campinas municipality: ANT (Santo Antônio das Mangueiras farm); RC (Ribeirão Cachoeira), 2) Valinhos municipality: VAL (Abrahão de Moraes Observatory), 3) Jundiaí municipality: JAPI1 (Serra do Japi 1); JAPI2 (Serra do Japi 2).

We selected two pair of locations whose distances between then were less than 10 kilometers (ANT and RC; JAPI 1 and JAPI 2). While the second pair is located in the same patch or forest continuum, there are a matrix of roads and farms connecting the first pair. Different matrix among sample sites could reveal distinct gene flow pattern. Small fragments of forest is represented by sample points ANT, RC and VAL. While JAPI samples were collected within a well conserved and large forest patch.

Table 1 shows the location and approximate size of each collection point, and the number of individuals $(\mathrm{N})$ in each area analyzed. All individuals were manually collected and taken alive to the laboratory. After identification, DNA was immediately extracted and stored in liquid nitrogen until further use.
Table 1: Description of the collection points. The size of the fragments studied is in hectares; coordinates of each fragment are obtained based on the global positioning system (GPS); N, number of individuals used in the analysis.

\begin{tabular}{cccc}
\hline Subpopulacion & Size (ha) & Coordinates & N \\
\hline ANT & 50 & $22^{\circ} 48^{\prime} 56^{\prime \prime} \mathrm{S}, 46^{\circ} 56^{\prime} 31^{\prime \prime} \mathrm{W}$ & 27 \\
RC & 245 & $22^{\circ} 49^{\prime} 56^{\prime \prime} \mathrm{S}, 46^{\circ} 55^{\prime} 40^{\prime \prime} \mathrm{W}$ & 22 \\
VAL & 100 & $23^{\circ} 00^{\prime} 35^{\prime \prime} \mathrm{S}, 46^{\circ} 57^{\prime} 43^{\prime \prime} \mathrm{W}$ & 29 \\
JAPI1 & 20.000 & $23^{\circ} 14^{\prime} 13^{\prime \prime} \mathrm{S}, 46^{\circ} 56^{\prime} 18^{\prime \prime} \mathrm{W}$ & 34 \\
JAPI2 & 20.000 & $23^{\circ} 13^{\prime} 37^{\prime \prime} \mathrm{S}, 46^{\circ} 58^{\prime} 06^{\prime \prime} \mathrm{W}$ & 20 \\
\hline
\end{tabular}

\section{Molecular Protocols}

Tissue from cephalothorax and/or legs was used for DNA extraction using Kit Wizard Genomic DNA Purification (Promega) following the suggestion of the manufacturer. To characterize the genetic variability of Aglacotenus lagotis, a genetic library for the selection of fragments containing microsatellite markers (SSR) was constructed. The characterization of the eight microsatellites obtained for Aglaoctenus lagotis has been previously described elsewhere [22], and this set of primers were used in the present work to obtain data. The PCR products were subjected to electrophoresis in $7 \%$ 23 polyacrylamide gels and the DNA bands were visualized by silver staining [23]. Genotypes were determined in relation to a 10bp DNA size standard 25 (Invitrogen).

Seven to ten individuals of each sample location were used for sequencing the COI gene. PCR amplification of the COI gene was performed in a final volume of $50 \mu \mathrm{L}$ and the reagents were added at the following concentrations: $15 \mathrm{ng}$ of DNA, 3.0 $\mathrm{mM}$ of magnesium, $0.2 \mathrm{mM}$ of $\mathrm{dNTP}, 0.4 \mu \mathrm{M}$ of each primer and $1 \mathrm{U}$ of Taq DNA polimerase. The primers used were: 1) $\mathrm{C} 1-\mathrm{J}$ 1751: 5'- GAGCTCCTGATATAGCTTTTCC- 3' [24]; e 2)fis C1N-2776: 5'- GGATAATCAGAATATCGTCGAGG-3' [25]. The PCR protocol used was: 1) initial denaturation at $95^{\circ} \mathrm{C}$ for 3 minutes, 2) 35 cycles at $94^{\circ} \mathrm{C}$ for 1 minute, $48^{\circ} \mathrm{C}$ for 1 minute, $72^{\circ} \mathrm{C}$ for 2 minutes; 3 ) and a final extension step at $72 \mathrm{oC}$ for five minutes. PCR reactions were checked by gel electrophoresis on $1 \%(\mathrm{w} / \mathrm{v})$ agarose gel run in $1 \mathrm{X}$ TBE buffer containing ethidium bromide at $100 \mathrm{~V}$ for 40 minutes.

The sequencing reaction was performed in both directions using primers C1-J-1751 and C1-N - 2776 from previously purified DNA using PEG precipitation. The BigDye Terminator Cycle Sequencing kit version 3.1 (Applied Biosystems) was used according to manufacturer's instructions and sequencing was carried out on the ABI PRISM 3100 Genetic Analyzer (Applied Biosystems). Quality of sequences was verified using the program Chromas lite (http://www.technelysium.com.au/ chromas_lite.html).

\section{Population Analyses}

The number of alleles per locus (A) and heterozygosities expected and observed $\left(\mathrm{H}_{\mathrm{O}}\right.$ and $\left.\mathrm{H}_{\mathrm{E}}\right)$ were analyzed using the program Genetix 4.05.2 [26]. The Hardy-Weinberg equilibrium and linkage disequilibrium were assessed (using Fisher's exact probability test) using the program GENEPOP version 3.4 [27]. Data from both tests were subjected to sequential Bonferroni 
correction [28]. Null allele frequency was estimated with Cervus version 3.0 [29]. The $\mathrm{F}_{\mathrm{ST}}$ values were analyzed using the Weir and Cockerham estimator [30] with the program fstat [31]. To analyze the effect of geographical distances between sample locations, a matrix containing estimates of pair wise $\mathrm{F}_{\mathrm{ST}}$ was compared to a matrix containing the pair wise distances using the Mantel test [32, 33] conducted using the program GENEPOP version 3.4. [27]. $\mathrm{F}_{\mathrm{ST}}$ Null allele correction was perfumed using Free $\mathrm{Na}$ [34]. The Program STRUCTURE [35] was used to define the most likely number of populations $(\mathrm{K})$ in the samples through Bayesian methods. Ten files containing parameter values $K=1$ to $K=10$ were tested with ten runs for each $\mathrm{K}$ value, assuming a mixture model (assuming that samples of a population are not isolated from one another), correlated allele frequencies, 10.000 burnins and 100.000 Markov chain Monte-Carlo (MCMC) simulations. The selection of the most appropriate $\mathrm{K}$ number was made using $\mathrm{K}$ values, according to the method proposed by Evanno et al. [36].

\section{Phylogenetic analysis}

The alignment of the COI mitochondrial gene sequences was performed using CLUSTAL W algorithm [37] in the software MEGA [38]. The haplotype network was constructed using TCS version 1.21 [39]. The genealogical relationships between individuals were reconstructed using phylogenetic methods since there were very divergent groups of individuals in the samples. The most appropriate substitution model for the sequences was Hasegawa, Kishino, and Yano [40] using the Akaike Information Criterion (AIC) inferred in Model Test program [41]. Phylogenetic reconstruction was performed using both maximum likelihood (ML). ML analysis was carried out using the program GARLI [42] with $1 \times 10^{6}$ generations of the algorithm, 1000 iterations, and 100 bootstrap repetitions, to determine the reliability for each internal node.

\section{RESULTS}

\section{Population Analysis}

The genotyping of all individuals collected using eight microsatellite loci revealed the presence of 71 alleles. Eighteen of which $(25.35 \%)$ were at frequencies below $5 \%$ and were therefore considered rare. Thirty-nine private alleles (54.9\%) were found, that is, they were observed exclusively in one of the five sample locations. The mean observed $\left(\mathrm{H}_{\mathrm{O}}\right)$ and expected $\left(\mathrm{H}_{\mathrm{E})}\right.$ heterozygozities and the mean inbreeding coefficients $\left(\mathrm{F}_{\mathrm{IS}}\right)$ are shown in Table 2. This results occurred probably due to the presence of null alleles (Table 3) which lead to departure of Hardy-Weinberg equilibrium in most populations (Table 4). Due to this fact, $\mathrm{F}_{\mathrm{IS}}$ values will not be discussed.

The global $\mathrm{F}_{\mathrm{ST}}$ value considered in the present work is $0.337(0.225-0.438)$ which was corrected to null alleles presence. Although, this value is not statistically different from original $\mathrm{F}_{\mathrm{ST}}$ value $0.342(0.240-0.430)$. The $\mathrm{F}_{\mathrm{ST}}$ pair wise values (Table 5) ranged from 0.106 to 0.507 . The STRUCTURE analysis indicated the presence of two populations (A and $\mathrm{B}$ ) in the sample locations sampled ( $\Delta K=2$, Figure 2$)$. The sample location JAPI 1 and most individuals of JAPI 2 and RC were assigned to population A (light gray), while the sample locations of ANT and VAL belong to population B (dark gray).

Table 2: Estimates of genetic diversity. $\mathrm{H}_{\mathrm{O}}$, observed heterozygosity, $\mathrm{H}_{\mathrm{E}}$ expected heterozygosity, $\mathrm{F}_{\mathrm{IS}}$, inbreeding coefficient. Values between brackets in the $\mathrm{H}_{\mathrm{O}}$ and $\mathrm{H}_{\mathrm{E}}$ columns correspond to the standard deviation and, in the $\mathrm{F}_{\mathrm{IS}}$ column, to the confidence interval of $95 \%$, determined by bootstrapping.

\begin{tabular}{cccc}
\hline Sample Site & $\mathbf{H}_{\mathbf{O}}$ & $\mathbf{H}_{\mathbf{E}}$ & $\mathbf{F}_{\mathbf{I S}}$ \\
\hline RC & $0.242(0.170)$ & $0.638(0.220)$ & $0.628(0.479-0.697)$ \\
ANT & $0.296(0.212)$ & $0.549(0.234)$ & $0.470(0.410-0.636)$ \\
VAL & $0.223(0.213)$ & $0.391(0.283)$ & $0.439(0.215-0.439)$ \\
JAPI & $0.328(0.269)$ & $0.505(0.325)$ & $0.354(0.242-0.477)$ \\
JAPI2 & $0.250(0.138)$ & $0.554(0.217)$ & $0.563(0.408-0.576)$ \\
\hline
\end{tabular}

Table 3: Null Allele's frequency in each sample site per locus. (*) significant values.

\begin{tabular}{cccccc}
\hline Locus & RC & ANT & VAL & JAPI1 & Japi2 \\
\hline Ala1 & 0.026 & $0.226^{*}$ & $0.240^{*}$ & 0.000 & 0.001 \\
Ala2 & $0.206^{*}$ & $0.167^{*}$ & $0.133^{*}$ & $0.061^{*}$ & $0.236^{*}$ \\
Ala3 & $0.250^{*}$ & $0.318^{*}$ & $0.322^{*}$ & $0.161^{*}$ & $0.084^{*}$ \\
Ala4 & 0.019 & $0.310^{*}$ & 0.000 & 0.000 & 0.000 \\
Ala5 & $0.167^{*}$ & 0.000 & 0.000 & 0.000 & 0.001 \\
Ala6 & $0.151^{*}$ & $0.221^{*}$ & $0.170^{*}$ & $0.110^{*}$ & $0.130^{*}$ \\
Ala7 & 0.001 & $0.227^{*}$ & $0.338^{*}$ & $0.338^{*}$ & $0.232^{*}$ \\
Ala8 & 0.001 & 0.000 & 0.183 & $0.155^{*}$ & $0.205^{*}$ \\
\hline
\end{tabular}

Table 4: Fisher's Exact test results reference to Hardy-Weiberg equilibrium adherence per locos in the five sample sites. (*) significant values which indicates departure from Hardy-Weiberg equilibrium.

\begin{tabular}{cccccc}
\hline Locus & RC & ANT & VAL & JAPI1 & Japi2 \\
\hline Ala1 & 0.224 & $0.004^{*}$ & $0.000^{*}$ & 1.000 & 1.000 \\
Ala2 & $0.000^{*}$ & 0.032 & 0.032 & 0.163 & 0.077 \\
Ala3 & $0.000^{*}$ & $0.000^{*}$ & $0.000^{*}$ & $0.000^{*}$ & 0.034 \\
Ala4 & 0.229 & $0.003^{*}$ & 1.000 & 1.000 & 0.458 \\
Ala5 & $0.000^{*}$ & 1.000 & 1.000 & 1.000 & 1.000 \\
Ala6 & $0.001^{*}$ & $0.001^{*}$ & 0.030 & 0.115 & 0.089 \\
Ala7 & 1,000 & $0.001^{*}$ & $0.000^{*}$ & $0.000^{*}$ & $0.000^{*}$ \\
Ala8 & 1,000 & 1.000 & $0.006^{*}$ & $0.004^{*}$ & $0.001^{*}$ \\
\hline
\end{tabular}

Table 5: $\mathrm{F}_{\mathrm{ST}}$ pairwise values of the studied populations using microsatellite data. The confidence interval, in brackets, of $95 \%$ was determined by bootstrapping.

\begin{tabular}{ccccc}
\hline & JAPI & RC & ANT & VAL \\
\hline \multirow{2}{*}{ RC } & 0.081 & & & \\
& $(0.032-0.142)$ & & & \\
\multirow{2}{*}{ ANT } & 0.287 & 0.204 & & \\
& $(0.172-0.414)$ & $(0.091-0.325)$ & 0.142 & \\
\multirow{2}{*}{ VAL } & 0.406 & 0.304 & $(0.040-0.223)$ & \\
& $(0.262-0.563)$ & $(0.168-0.445)$ & 0.429 & 0.507 \\
\multirow{2}{*}{ JAPI1 } & 0.106 & 0.175 & $(0.246-0.599)$ & $(0.370-0.613)$ \\
\hline
\end{tabular}

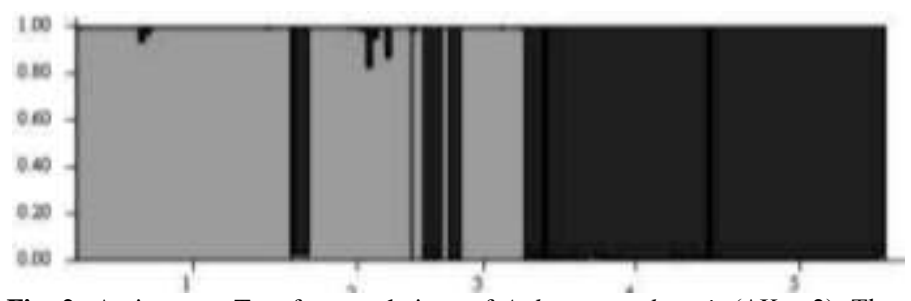

Fig. 2: Assignment Test for populations of Aglaoctenus lagotis $(\Delta \mathrm{K}=2)$. The individuals are represented by colored vertical bars. The same color in different individuals indicates that they belong to the same population. Different colors in the same individual indicate the percentage of a shared genome between each population. The ordinate axis shows the coefficient of participation of the individual in each population. The numbers on the $\mathrm{x}$-axis indicate geographical regions where individuals were collected: 1) JAP11, 2) JAP12, 3) RC, 4) ANT, 5) VAL. Population A is represented in light gray and population B in dark gray. 


\section{Phylogenetic Analysis}

The haplotype network and the phylogenetic reconstruction based on COI sequences are shown in Figures 3 and 4. In both analysis, sequences obtained were separated into two significant major clades, each with three haplotypes (Figures 3 and $4)$.

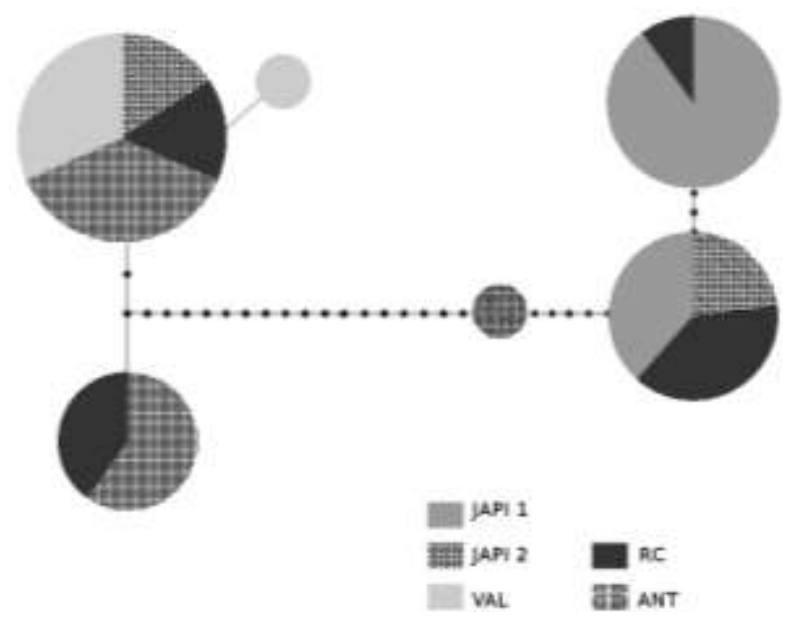

Fig. 3: Haplotypes network of mitochondrial COI gene of A.lagotis. Every large circle is an observed haplotype. Each line represents one mutational step and black dots represent the inferred non-sampled haplotypes. The colors represent the subpopulation in which each haplotype was found.

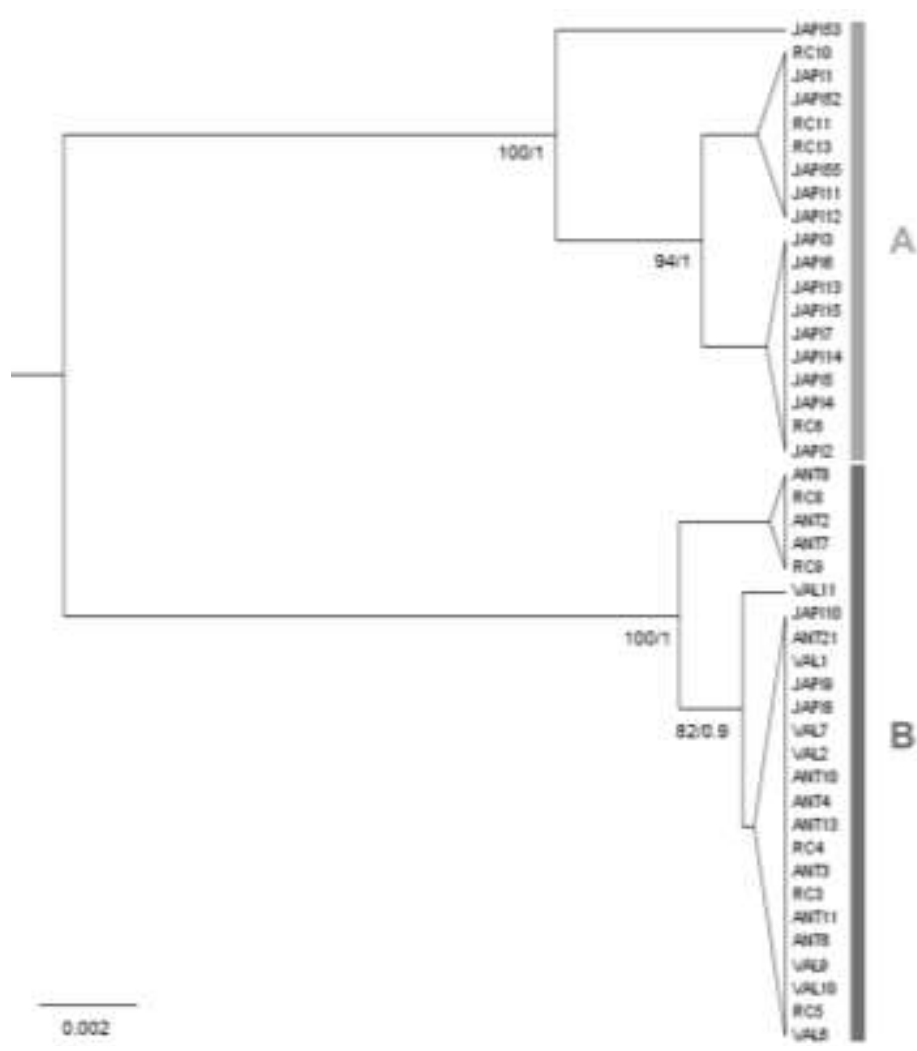

Fig. 4: Phylogenetic inference obtained by maximum likelihood (ML). Each branch corresponds to one of the six haplotypes found and are separated in two major clades (A and B). Individuals of each sample sites are indicated. Support for branches is indicated by bootstrap. Scale bar units are substitutions per site.

\section{Population Analysis within evolutionary lineages}

The F statistics were recalculated considering the separation of individuals, regardless of the collection site, into two evolutionary lineages (A and B), the divergence of which can be detected in the data obtained with both nuclear and mitochondrial markers. Of the 71 microsatellite alleles found, $32(45.07 \%)$ were private to lineage A and $26(36.62 \%)$ to lineage B, giving a total of $58(81.69 \%)$ private alleles. The $\mathrm{F}_{\mathrm{ST}}$ value found for lineage $\mathrm{A}$ is $0.118(0.027-0.193)$ and for lineage $\mathrm{B}, 0.142(0.042-0.223)$. The $\mathrm{F}_{\mathrm{ST}}$ value between lineages $\mathrm{A}$ and $\mathrm{B}$ is $0.388(0.235-0.516)$.

\section{DISCUSSION}

\section{Cryptic diversity}

Two lines of evidence suggest the presence of cryptic diversity in the sampled locations of A. lagotis. First, the STRUCTURE analysis indicated the existence of two populations with minimum gene flow between them $(K=2$, Figure 2$)$. In addition, analysis of the COI gene sequences indicated the presence of two evolutionary lineages (A and B), differing on average by $3.7 \%$. Those lineages grouped the individuals identically to the STRUCTURE analysis, regardless of where they were collected (Figure 3 and 4).

The subsequent analysis of the nuclear data show that within the evolutionary lineages the genetic structure is significantly lower than between lineages. Moreover, the percentage of divergence found between lineages in the COI gene is compatible with that found in distinct species.

The COI gene has been extensively studied in animals, particularly in relation to inter and intra-specific diversity. Between pairs of species of the same genus, Hebert and colleagues (43) showed that in $98 \%$ of them, the divergence in the COI gene is greater than $2 \%$. In a spider study, that includes 361 species of 19 genera, was found an average intra-specific divergence of $2.15 \%$ in the COI gene sequence, while the average inter-specific divergence was set at $6.77 \%$ [44]. In the family Lycosidae, the average divergence between species of the same genus was $2.84 \%$ [44]. Thus, the divergence found between A. lagotis lineages $(3,7 \%)$ is compatible with those between Lycosidae congeneric species.

Furthermore, several individuals from different lineages are sympatric, strongly suggesting gene flow interruption between lineages which could be refereed as a complete speciation process. The cryptic genetic diversity observed in Aglaoctenus lagotis does not match the morphological and behavioral evidence as yet described for the species [14]. Therefore, additional studies on life history, morphology, behavior, and spatial distribution are needed to decide whether the evolutionary lineages obtained in this study are indeed distinct species.

\section{Genetic Diversity and Geographic distribution}

We have found moderated structure levels among sample locations within lineages $\left(\mathrm{F}_{\mathrm{ST}} \mathrm{A}=0.118 ; \mathrm{F}_{\mathrm{ST}} \mathrm{B}=0.142\right)$, which indicates that these sites are not completely isolated from each 
other. Studies with spiders have reported gene exchange between populations in fragmented landscapes at distances within 25 kilometers $[45,46]$, due to air dispersal or ballooning. Thus, aerial dispersion could be possibly preventing a complete isolation among sample locations. In addition, in the present study area, there were a number of other small fragments that could serve as steppingstones between the collection points, increasing connectivity and gene flow. Although we should consider ballooning presence, aerial dispersal alone cannot explain geographic diversity distribution in A. lagotis. In fact, our data, both nuclear and mitochondrial, does not follow a recognizable geographic pattern. For instance, we did not find a positive correlation between geographic distance and genetic structure in Mantel test (data no show). Possibly, the presence of two sympatric evolutionary lineages enhance complexity in diversity distribution scenario that could only be reveled in future studies. The present study was carried out in a small geographic scale, thus the possible existence of further genetic lineages of A. lagotis might not be dismissed. Diversity distribution of A. lagotis lineages in the studied fragments might be explained by evolutionary, metapopulational and ecological factors yet to be established.

\section{CONCLUSION}

We have found two different genetic lineages of $A$. lagotis in the sample sites studied herein. This crypitic diversity indicate that genetic diversity distribution of this species could be even more complex in a larger scale. The hypotheses that lineages found represent distinct species cannot be confirmed until further studies have been carried out. However, regardless of its taxonomic classification, the genetic lineages should be considered as individual units in future evolutionary studies of this species.

\section{ACKNOWLEDGMENTS}

We thank Kaiser Dias Schwarcz for the technical support, as well as Marcelo Gonzaga and Adalberto Santos for the help in field expeditions and material collect. We are grateful to FAPESP (Fundação de Amparo à Pesquisa do Estado de São Paulo) for the financial support.

\section{REFERENCES}

1. Platnick NI. An abundance of spiders. Natural History. 1995; 104 (3): 50-52.

2. World Spider Catalog [Internet]. Natural History Museum Bern, version 16.5 [updated $2015 \mathrm{Jul} 10$; cited $2015 \mathrm{Jul} 10$ ]. Avaiable from http://research.amnh.org/entomology/spiders/catalog/index.Html.

3. Santos AJ, Brescovit AD. A revision of the south american spider genus Aglaoctenus tullgren 1905 (aranae, lycosidae, sosippinae). Andrias. 2001; 15: 75-90.

4. Brescovit AD, Oliveira U, Santos AJ. Spiders (Araneae, Arachnida) from São Paulo State, Brazil: diversity, sampling efforts, and state-ofart. Biota Neotrop. 2001;11(1):717.

5. Brescovit AD. Araneae. In: Brandão CRF, Vasconcelos EM, editors. Biodiversidade do Estado de São Paulo, Brasil: Síntese do conhecimento ao final do seculo XX, São Paulo: Fapesp; 1999, p. 4556.
6. Ford MJ. Locomotory activity and predation strategy of the wolf spider Pardosa amentata (Clerck) (Lycosidae). 1978; Animal Behavior 26: 31-35.

7. Foelix RF. Biology of Spiders. 2nd ed. New York: Oxford University Press, 1996.

8. Wise DH. Spiders in Ecological Webs. 1st ed. Cambridge: Cambridge University Press, 1993.

9. Gonzaga MO. Sociedade e cuidado parental. In: Gonzaga MO, Santos AJ, Japyassu HF, editors. Ecologia e comportamento de aranhas, Rio de Janeiro: Editora Interciência; 2007, p. 185-208.

10. Stefani V, Del-claro K, Silva LA; Guimarães B, Tizo-Pedroso E. Mating behaviour and maternal care in the tropical savanna funnelweb spider Aglaoctenus lagotis Holmberg (Araneae: Lycosidae) Journal of Natural History. 2001; 45 (17): 1119-1129.

11. Vieira C, Japyassú HF, Santos AJ, Gonzaga MO. Teias e forrageamento. In: Gonzaga MO, Santos AJ, Japyassu HF, editors. Ecologia e comportamento de aranhas, Rio de Janeiro: Editora Interciência; 2007, p. 45-66.

12. Riechert, SE. Web-site selection in the desert spider Agelenopsis aperta. Oikos. 1976; 27: 311-315.

13. Ribeiro MC, Metzger JP, Martensen AC, Ponzoni FJ, Hirota MM. The brazilian atlantic forest: How much is left, and how is the remaining forest distributed? implications for conservation. Biological Conservation. 2009; 142 (6): 1141-1153.

14. Myers N, Mittermeier RA, Mittermeier CG, da Fonseca GAB, Kent J. Biodiversity hotspots for conservation priorities. Nature. 2000; 403 (6772): 853-858.

15. Laurance WF, Nascimento HEM, Laurance SG, Andrade A, Ribeiro JElS, Giraldo JP, Lovejoy TE, Condit R, Chave J, Harms KE, D'Angelo S. Rapid decay of tree-community composition in amazonian forest fragments. Proceedings of the National Academy of Sciences of the United States of America. 2006; 103 (50): 19010-14.

16. Groeneveld J, Alves L, Bernacci L, Catharino E, Knogge C, Metzger J, Putz S, Huth A. The impact of fragmentation and density regulation on forest succession in the atlantic rain forest. Ecological Modelling. 2009; 220 (19):2450-2459

17. Schwarcz KD, Pataca CL, Abreu AG, Bariani JM, Macrini CMT, Solferini VN. Fragmentation effect on Astronium graveolens Jacq. (Anacardiaceae) and Metrodorea nigra A. St-Hil. (Rutaceae): Two species with distinct seed dispersion strategies. Botanical Journal of Linnean Society. 2010; 164 (3): 326-336.

18. Putz S, Groeneveld J, Alves LF, Metzger JP, Huth A. Fragmentation drives tropical forest fragments to early successional states: a modelling study for brazilian atlantic forests. Ecological Modelling. 2011; 222 (12): 1986-1997.

19. Mendes CP, Ribeiro MC, Galetti M. Patch size, shape and edge distance influence seed predation on a palm species in the Atlantic forest. Ecography. 2005 38: 001-011. doi:10.1111/ecog.01592

20. Baldissera R, Rodrigues ENL, Hartz SM. Metacommunity Composition of Web-Spiders in a Fragmented Neotropical Forest: Relative Importance of Environmental and Spatial Effects. Plos one. 2012 7;10:e48099. doi: 10.1371/e48099

21. Moreira VSS, Del-Claro K. Oviposition and post-embryonic development of Aglaoctenus lagotis (Araneae: Lycosidae). Zoologia, 2001; 28 (5): 565-570

22. Abreu AG, Albaina A, Alpermann TJ, Apkenas VE, BankheadDronnet S, Bergek S, Berumen M L, CHO C-H, Clobert J, Coulon A, De Feraudy D, Estomba A, Hankeln T, Hochkirch A, Hsu T, Huang, T Irigoin $\mathrm{X}$, Iriondo $\mathrm{M}$ Kay, Kathleen M, Kinitz T, Kothera L, Le Hénanff, M, Lieutier F, Lourdais O, Macrini, C M T, Manzano C, Martin C, Morris VRF, Nanninga G, Pardo MA, Plieske J, Pointeau S, Prestegaard T, Quack M, Richard M, Savage HM, Schwarcz KD, Shade J, Simms EL, Solferini VN Permanent Genetic Resources added to Molecular Ecology Resources Database 1 October 2011 - 30 November 2011. Molecular Ecolology Resourses. 2011; 12(2):374376.

23. Sanguinetti CJ, Dias-Neto E, Simpson AJG. Rapid silver staining and recovery of PCR products separated on polyacrylamide gels. Biotechniques. 1994; 17(5): 915-919. 
24. Simon C, Frati F, Beckenbach A, Crespi B, Liu H, Flook P. Evolution, weighting, and phylogenetic utility of mitochondrial gene sequences and a compilation of conserved polymerase chain reaction primers. Annals of the Entomological Society of America. 1994; 87(6): 651 701.

25. Hedin MC, Maddison WPA. Combined molecular approach to phylogeny of the jumping spider subfamily dendryphantinae (araneae: Salticidae). Molecular Phylogenetics and Evolution. 2001; 18 (3): 386403.

26. Belkhir K, Borsa P, Chikhi L, Raufaste N, Bonhomme, editors. F. GENETIX 4.05, logiciel sous windows tm pour la genetique des populations [internet]. Montpellier: Université de Montpellier II; 2004. [cited 2015 May 15]. Available from: http://kimura.univmontp2.fr/genetix/.

27. Raymond M, Rousset F. GENEPOP (version 1.2) population genetic software for exact tests and ecumenicism. Journal of Heredity. 1995; 86 (3): 248-249.

28. Marshall, TC, Slate, J, Kruuk, LEB \& Pemberton, JM. Statistical confidence for likelihood-based paternity inference in natural populations. Molecular Ecology. 1998; 7(5): 639-655.

29. Rice WR. Analyzing tables of statistical tests. Evolution. 1989; 43(1): 223-225.

30. Weir BS, Cockerham CC. Estimating $F$-statistics for the analysis of population structure. Evolution. 1984; 38 (6): 1358-1370.

31. Goudet, J. FSTAT version 1.2: a computer program to calculate fstatistics. Journal of Heredity. 1995; 86 (6): 485-486.

32. Mantel N. Detection of a disease clustering and a generalized regression approach. Cancer Research. 1967; 27 (2):209-220.

33. Mantel N, Valand RS. A technique of nonparametric multivariate analysis. Biometrics. 1970; 26 (3):547-558.

34. Chapuis, MP and Estoup A. Microsatellite null alleles and estimation of population differentiation. Molecular Biology and Evolution . 2007; 24 (3): 621-631.

35. Pritchard JK, Stephens M, Donnelly P. Inference of population structure using multilocus genotype data. Genetics. 2000; 155 (2): 945-959.

36. Evanno G, Regnaut S, Goudet J. Detecting the number of clusters of individuals using the software structure: a simulation study. Molecular Ecology. 2005;14 (8): 2611-2620

37. Thompson JD, Gibson TJ, Plewniak F, Jeanmougin, F, Higgins, DG. The Clustral $\mathrm{X}$ windows interface: flexible strategies for multiple sequence alignment aided by quality analysis tools. Nucleic Acids Research. 1997; 25 (24):4876-4882.

38. Tamura K, Dudley J, Nei M, Kumar S Mega4: Molecular evolutionary genetics analysis (mega) software version 4.0. Molecular Biology and Evolution. 2007; 24 (8): 1596-1599.
39. Clement, M, D Posada, KA Crandall TCS: a computer program to estimate gene genealogies. Molecular Ecology. 2000; 9 (10):16571659.

40. Hasegawa M, Kishino H, Yano T. Dating of the human-ape splitting by a molecular clock of mitochondrial dna. Journal of Molecular Evolution. 1985; 22 (2):160-174.

41. Posada, D, Crandall KA Modeltest: testing the model of dna substitution. Bioinformatics. 1998; 14 (9): 817-818.

42. Zwickl DJ, editor. Genetic algorithm approaches for the phylogenetic analysis of large biological sequence datasets under the maximum likelihood criterion [internet]. Austin: University of Texas; 2006 [cited 2015 May 10]. Avaiable from: http://www.zo.utexas.edu/faculty/ antisense/zwicklDissertation.pdf.

43. Hebert PDN, Ratnasingham S, deWaard JR. Barcoding animal life: cytochrome $\mathrm{c}$ oxidase subunit 1 divergences among closely related specieis. Proceedings of Royal Society of London B. 2003; 270 (S1): S96-S99.

44. Robinson EA, Blagoev GA, Hebert PDN, Adamowicz SJ. Prospects for using DNA barcoding to identify spiders in species-rich genera. ZooKeys. 2009; 16: 27-46.

45. Ramirez MG, Fandino LB. Genetic variability and gene ow in metepeira ventura (araneae, araneidae). Journal of Arachnology. 1996; 24 (1):1-8.

46. Ramirez MG, Haakonsen KE. Gene flow among habitat patches on a fragmented landscape in the spider argiope trifasciata (araneae: Araneidae). Heredity. 1999; 83 (5): 580-585.

\section{How to cite this article:}

Macrini CMT, Peres EA, Solferini VN. Cryptic diversity of Agloactenus lagotis (Araneae, Lycosidae) in the Brazilian Atlantic Rainforest: evidence from microsatellite and mitochondrial DNA sequence data. J App Biol Biotech, 2015; 3 (06): 009-014. DOI: 10.7324/JABB.2015.3602 